Article

\title{
The Dark Side of Descriptive Representation: Bodies, Normalisation and Exclusion
}

\author{
Petra Meier ${ }^{1, *}$ and Eline Severs ${ }^{2}$ \\ ${ }^{1}$ Department of Political Science, University of Antwerp, 2000 Antwerp, Belgium; E-Mail: petra.meier@uantwerpen.be \\ 2 Department of Political Science, Vrije Universiteit Brussel, 1050 Brussels, Belgium; E-Mail: eline.severs@vub.be \\ * Corresponding author
}

Submitted: 8 February 2018 | Accepted: 2 July 2018 | Published: 14 September 2018

\begin{abstract}
This contribution elaborates on the role model function of descriptive representatives. We seek to elaborate on potentially negative effects of role models, as we think they can endanger a feminist project of dismantling hierarchical power relations. When society attributes descriptive representatives the position of role models, the former no longer simply stand for their groups in a socio-demographic manner. Role models also stand for them in an exemplary manner, allowing them to prescribe a set of appropriate or desirable traits and behaviours. The presence and performance of role models, thus, powerfully shapes the context to the representation of disadvantaged groups. Because of their exemplary function, the personal experiences and life trajectory of descriptive representatives may be elevated to a standard; potentially causing the interests and demands of other group members to be considered abnormal or marginal. Also, role models may, paradoxically, promote exclusion. Representatives' social differences provide them with powerful symbolic resources to speak on behalf of their group. While such authority may help them put previously overlooked interests on the agenda, their personal take on things may limit the terms of the debate, as it cuts out alternative intersections of social positions; making it difficult to voice alternative group perspectives. In this regard, role models may hamper the feminist project which precisely implies giving voice to excluded groups so as to broaden the range of voices articulated.
\end{abstract}

\section{Keywords}

alternative voices; descriptive representation; feminism; political role models; symbolic representation

\section{Issue}

This article is part of the issue "The Feminist Project under Threat in Europe", edited by Mieke Verloo (Radboud University, The Netherlands) and David Paternotte (Université Libre de Bruxelles, Belgium).

(C) 2018 by the authors; licensee Cogitatio (Lisbon, Portugal). This article is licensed under a Creative Commons Attribution 4.0 International License (CC BY).

\section{Introduction}

Since the 1990s, a growing number of women and citizens with migration backgrounds entered parliament. This descriptive diversification of politics has been accompanied by an expanding literature that examines the impact of such diversification. This literature has theorised the impact of descriptive representation in predominantly positive terms (Dolan, 2006). Echoing Anne Phillips' influential book, The Politics of Presence (1995), descriptive representatives are generally conceived as contributing to the legitimacy of the representative system. Their presence in central decision-making institu- tions corrects historical injustices and may help restore trust between the state and disadvantaged groups. Their presence may equally help place previously overlooked interests on the political agenda and may, in doing so, improve the quality of deliberation. Finally, the presence of descriptive representatives also affirms the ability to rule of members of disadvantaged groups: having like people in parliament may empower members of historically disadvantaged groups and enhance their selfesteem (Mansbridge, 1999; Phillips, 1995).

However, empirical research has found the effects of descriptive representation to be mixed: not every descriptive representative promotes the interests of dis- 
advantaged groups or enhances their political engagement. Having a like candidate or politician does not suffice to represent, inspire and empower members of disadvantaged groups. Much depends on the conditions that facilitate such presence and the particular performance of representatives. Their positive impact is, for instance, greatly affected by the extent to which people regard them as competent (Atkeson, 2003; Dolan, 2006; Franceschet, Krook, \& Piscopo, 2012).

In spite of these findings, scholars continue to build their hypotheses around the positive difference that descriptive representatives can make (for noteworthy exceptions, see Fenno, 2003; Gay, 2002). While scholars accept that descriptive representatives may, in themselves, not be sufficient to yield the hypothesised positive effects on disadvantaged groups' interest representation and political engagement, they nonetheless continue to treat descriptive representation as an asset to representative democracy. As a result, the potentially negative effects of descriptive representation remain undertheorized.

In this contribution, we seek to elaborate on these potentially negative effects, as we think they endanger a feminist project of dismantling of hierarchical power relations. To raise attention to the ambiguous relation between descriptive representation and empowerment, we scrutinise the role model function of descriptive representatives. Clearly, we do not contest that political role models are valuable. We, however, argue that the concept of political role models remains undertheorized, and that closer attention must be paid to the constitutive effects of role models. When society labels descriptive representatives as role models, they are not simply seen as standing for their social groups in a sociodemographic manner. Instead, they are conceived as standing for their social groups in an exemplary manner: while being like other group members, their professional successes also set them apart (Severs \& de Jong, 2018). The label of role model, in this regard, already creates a context to the representation of historically disadvantaged groups: it specifies what society expects from disadvantaged groups and how it wants them to behave and interact with more privileged groups. Set against this backdrop, representatives' performance (i.e., their attire, appearance, acts) can strengthen or help attenuate the expectations that are hierarchically imposed on disadvantaged groups. Representatives' impact needs not be voluntarist: because they are seen as standing for their social group, everything they do, the ways in which they (do not) behave, the type of representative claims they (do not) formulate affects, in a powerful manner, how their social group is conceived.

We put these constitutive effects (i.e., how social groups and their relations to others are defined) at the centre of our theoretical framework and argue that descriptive representatives are in themselves neither good nor bad. The impact of role models depends on how they perform their (ascribed or self-identified) group identi- ties, and how such performances affect the distribution of power among social groups. This is where role models may hamper a feminist project. Much depends on how descriptive representatives interact with the role model function that is explicitly or implicitly ascribed to them The exemplary function of role models may elevate the personal experiences and life trajectory of descriptive representatives to a standard. Such a standard leads to normalisation, i.e., ascribing how group members should behave and what the group should be about. In addition to this normalisation, role models may, somewhat paradoxically, promote exclusion. Representatives' social differences provide them powerful symbolic resources to speak on behalf of their group. While such authority may help them put previously overlooked interests on the agenda (Phillips, 1995), their personal take on things may also limit the terms of the debate, as it cuts out alternative intersections of social positions; making it difficult to voice alternative group perspectives. Research (e.g., Strolovitch, 2006) has documented that group advocacy predominantly promotes the interests of privileged subgroups. Descriptive representatives' role model function may, thus, provide them powerful symbolic resources to suppress the range of options and keep the issues that affect the most disadvantaged of the table (cf. Schattschneider, 1960). In this respect role models may hamper the feminist project, which has traditionally been about giving voice to women and other traditionally discriminated against or excluded groups and which has tried, by supporting group members to speak for themselves, to broaden the range of voices articulated. Such diversification(drawing attention to the intersectional character of group members' identities and experiences) comes at risk when too much attention is attributed to the particular positionality of a role model.

So as to better understand the potential harms caused by descriptive representatives, we reconsider the interplay between descriptive, substantive and symbolic representation. Our argument continues over four sections. First, we discuss the literature on descriptive, substantive and symbolic representation. In the second section, we offer our conceptualisation of symbolic representation and specify its relationship to descriptive representation. We argue that the language of descriptive representation is too passive to understand the potentially negative impact of role models. Descriptive representation ignores how representatives co-constitute the subjects they stand for: it is premised on an aesthetic fit of socio-demographic characteristics between an agent and a subject, and audiences' acknowledgement of such a fit (Pitkin, 1967). Symbolic representation, instead, directs attention to representatives' ability to craft an aesthetic fit; using their group identities to prescribe appropriate group behaviour (cf. Diehl \& Escudier, 2014). When conceived as a role model, descriptive representatives not only stand for their social group in socio-demographic terms, but they equally hold normative power over them. This effect of normalisation can 
only be understood through the lens of symbolic representation, and the ways in which role models become symbolic agents of the subjects they are seen to stand for (Lombardo \& Meier, 2014).

In the third section, we turn to the Nieuw-Vlaamse Alliantie (N-VA) [Flemish-Nationalist party] as an illustration of the ways in which role models may turn into agents of normalisation and how this may negatively affect the inclusiveness of representation processes. The $\mathrm{N}-\mathrm{VA}$ is a regionalist party and strives for a peaceful secession of Flanders from Belgium. In recent years, the N-VA has become the largest party of Flanders. It currently presides the Flemish government and is one of the main coalition partners in the federal government. In our discussion of the N-VA, we will focus on two politicians. The first case refers to Liesbeth Homans. Following the 2014 regional elections, Homans was appointed Minister of Internal Affairs, Integration, Housing, Equal Opportunities and Poverty Reduction to the Flemish government. The portfolio of Homans is not arbitrary: she is known for her personal experiences with childhood poverty, and she frequently alludes to such personal experiences. Zuhal Demir features as our second case. Demir's parents are Alevi Kurds who in the 1970s moved from Turkey to Flanders, attracted by the financial prospects of working in the coalmining industry. In 2010, Demir was for the first time elected into the Belgian federal parliament. Her political fame rose quickly. In February 2017, she was appointed State Secretary of Poverty Reduction, Equal Opportunities, People with a Disability, Urban Policy and Science Policy to the federal government. In the fourth section, we link our cases to the argument set out before. Finally, in the conclusion we specify the main takeaway points.

\section{Descriptive Representatives}

The gender and politics literature owes much to Hanna Pitkin's (1967) foundational work The Concept of Representation. In this work, Pitkin defined political representation as "the making present of something absent" and differentiated four dimensions of representation (i.e., formal, descriptive, symbolic and substantive representation). The gender and politics literature most profoundly invested in the dimension of substantive representation (that Pitkin herself had placed at the heart of representative democracy) and sought to explain its relation to descriptive representation.

This literature is premised on the assumption that, as the result of their history, experiences with structural inequalities and relationships with other group members, members of historically disadvantaged groups are likely to understand social events in a different way than individuals belonging to privileged groups. In the same manner, affected by their social locations, privileged groups are also less likely to understand and acknowledge the relevance of minority perspectives (Alcoff, 1991, p. 7; Young, 1989, p. 264). The premise that representatives' social locations have an epistemic impact and affect their capacity to represent others lies at the core of the theoretical literature that advocates an institutionalised presence for historically disadvantaged groups (Dovi, 2002; Phillips, 1995; Williams, 1998). The insight that representatives' social locations shape their understanding of political issues and priorities revealed the limitations of traditional mechanisms of accountability that are rooted in representatives' relations to an anonymous electorate. Especially in contexts where distrust between social groups is high and disadvantaged groups' interests may not yet have crystallised, representatives' social identities are crucial to promote fair representation (Mansbridge, 1999).

However, when it comes to proving the relevance of descriptive representation, the findings are mixed. Research revealed that the relationship between descriptive and substantive representation is not deterministic but should be conceived as probabilistic at best (Dodson, 2006). Sharing the outward signs of having lived through the same experiences does not automatically cause descriptive representatives to advocate the interests of their social group. Not all female politicians, for instance, seek to promote women's interests. At the same time, some male politicians fervently advocate the interests of women. In addition, scholars found that the relationship between descriptive and substantive representation varies greatly depending on the type of representative activities under study (e.g., parliamentary interpellations, written questions, etc.) and the specific operationalisation of women's interests (Celis, Childs, Kantola, \& Krook, 2008). These insights, along with black feminist critiques on the white, feminist, middle-class biases in scholarly operationalisations of women's interests, has promoted inductive approaches to studying social group representation. These approaches attribute closer attention to the nature, type and range of political interests claimed on behalf of social groups.

In parallel to this literature on the descriptivesubstantive relationship, scholars have begun to explore the relationship between descriptive and symbolic representation. This literature is premised on the belief that the presence of historically disadvantaged groups in central decision-making institutions may equally increase the self-esteem of members of historically disadvantaged groups and promote their capacity to assume leadership positions themselves. Female candidates may act as role models, sending, as Dolan (2006, p. 688) argued, "the signal that politics is no longer an exclusive man's world and that female participation is an important and valued act".

Phillips (1995, p. 63) herself dismissed the role model argument as less interesting and without much bearing on democratic politics. Others (e.g., Dovi, 2002, p. 730) have, in contrast, argued that the ability to inspire and to act as an example for historically disadvantaged groups may be crucial for mobilising members from that group. In the context of past and sometimes continuing injus- 
tices, the presence of role models may positively affect the political engagement (knowledge of, interest in and participation in politics) of members of disadvantaged groups. At the same time, however, scholars have also problematised the possibility for manipulation. Scholars have, for instance, pointed to the possibility that descriptive representatives may enjoy a "representational leeway on policy matters" (Fenno, 2003, p. 32). Thanks to their descriptive characteristics, representatives can more easily make emotional appeals of likeness with members of disadvantaged groups; potentially causing the latter to extend their support even when representatives do not promote their substantive interests (Gay, 2002; Mansbridge, 1999).

Studies on women and ethnic minorities (Atkeson, 2003; Dolan, 2006; Jones, 2014) have, however, invalidated the thesis of blind loyalty: women and ethnic minorities have greater knowledge of their descriptive representatives' actions (compared to the actions of other representatives) and weigh these actions more carefully when evaluating them. This suggests that members of historically disadvantaged groups hold higher expectations toward their representatives (Severs \& de Jong, 2018). Studies have, in addition, confirmed the positive impact of the presence of disadvantaged groups: when female candidates run for and win office, women express greater interest in politics (Reingold \& Harrell, 2010; Verba, Burns, \& Schlozman, 1997), are more likely to discuss politics (Atkeson, 2003), and display greater levels of political participation (Campbell \& Wolbrecht, 2006). Women are also more likely to recognise the names of female candidates than male candidates (Dolan, 2011; Reingold \& Harrell, 2010). The positive impact of female candidates on women's levels of political engagement is likely mediated by female candidates' greater propensity to campaign on issues of interest to women, and the greater visibility of women's issues in these races (Dolan, 2006).

Research, however, also shows that the impact of descriptive representatives on the political engagement of members of historically disadvantaged groups is mediated by contextual factors. Simply having a like candidate on the ballot or a like person in parliament is not enough to stimulate political engagement. In a longitudinal study on American elections, Atkeson (2003), for instance, found that women who lived in states with female candidates were more likely to discuss politics and had higher levels of political knowledge than women who experience male-only races. This effect was, however, conditional on the perceived competitiveness of female candidates: when candidates are conceived as mere tokens, they fail to elicit the expected positive effects (cf. Bobo \& Gilliam, 1990; Hansen, 1997; Tate, 1991).

\section{Symbolic Representation and Normalisation}

Although empirical research has invalidated the fear that descriptive representatives would yield blind loyalty, this is not the only danger conceivable. As we seek to demonstrate in this contribution, representatives' descriptive characteristics form powerful symbolic resources allowing them to claim experiential authority in representation processes. Such authority carries a risk of normalisation: namely, that representatives' personal, and invariably limited, experiences are elevated to the level of standards against which all other group members are measured and may, by their failure to achieve comparable successes, be found wanting or deviant (cf. Young, 2006, p. 96). The one-directional character of descriptive representation helps explain why this risk has insufficiently been theorised in the literature. The quality of descriptive representation is measured by the extent to which the diversity of parliament maps onto sociodemographic reality. In this sense, descriptive representation invokes a relationship with constituents that are, presumably, readily given in society.

Because the dimension of descriptive representation is premised on a logic of mimesis (Pitkin, 1967), it prevents any serious interrogation of the ways in which descriptive representatives also co-constitute the subjects they are seen to stand for (two-directionality). To understand how descriptive representatives may inverse the representative relationship (from mimicking reality to coconstituting reality), we need to add the dimension of symbolic representation to our analyses. Only this dimension allows for understanding how descriptive representatives, once attributed the exemplary function of role model, become symbolic agents that prescribe (topdown relationships) inasmuch as they describe (bottomup relationships) (Lombardo \& Meier, 2014).

Before we proceed further, it is important to point out that within the empirical literature, symbolic representation is often understood in terms of the attitudinal and behavioural effects that descriptive representatives elicit among members of historically disadvantaged groups. Symbolic representation is often equated to constituents' feelings of being represented, included or recognised (Lawless, 2004, p. 81). Such an approach, however, subsumes symbolic representation under the header of descriptive representation, and treats it as a by-product of the latter; as opposed to a dimension in its own right (Lombardo \& Meier, 2014). To better understand the relationship between descriptive and symbolic representation, we advocate a reappraisal of Pitkin's (1967) original discussion thereof.

Pitkin's treatment of symbolic representation clarified that representation need not necessarily involve human activity but may equally be realised through inanimate objects, such as a flag or anthem "standing for" a nation (Pitkin, 1967, 93). It is precisely this evocative power that sets symbolic representation apart from descriptive representation. In descriptive representation, the relation between parliament and the people can be judged on the basis of rationally justifiably and objectively verifiable criteria, such as the extent to which parliament reflects descriptive characteristics that are 
judged relevant by a political community at a given time-such as geographical area of birth, occupation, ethnicity or gender (Pitkin, 1967, p. 100). In symbolic representation, by contrast, there are no rational justifications. "Symbol-making", Pitkin (1967, p. 101) argued, "is not a process of rational persuasion, but of manipulating affective responses and forming habits".

In this sense, symbolic representation operates as the pendant to descriptive representation. The success of both dimensions depends on the ability of the representative agent to establish a meaningful relationship with the subject; allowing the former to be seen as standing for the latter. But whereas descriptive representation is judged by the extent to which it mirrors a society's descriptive characteristics, the success of symbolic representation hinges upon representatives' ability for mobilising people and inducing relevant audiences to conceive of some of their features (e.g., life trajectory, personality traits) as characteristic or prototypical of the group (cf. Diehl, 2015; Lowndes, 2013). Clearly, there are restrictions to the creativity of a representative: representative relationships cannot be forged out of thin air (Saward, 2010). Symbols' capacity to stand for (a set of) the people depends upon their fit with prevailing socio-historical, cultural and political repertoires. Symbols, however, also have the capacity to reaffirm, or else reinterpret and transform, these repertoires by appealing to people's sentiments and emotions. It is this capacity that defines the prescriptive or normalising impact of symbolic representation.

This insight lies at the heart of Lombardo and Meier's work on symbolic representation. In The Symbolic Representation of Gender. A Discursive Approach (2014), they argue that political symbols do not passively stand for political reality but actively contribute to constituting that reality. Political symbols only appear to be passive containers or mirrors of reality because they can draw upon conventional and routinized associations between symbol and subject (cf. Disch, 2012; Saward, 2010). The evocative power of a public statue, for instance, originates from prevailing (invariably selective and contingent) understandings routinely associated with a people, such as courage and self-sacrifice (as expressed by World War memorials). While re-iterating routinised associations, statues however also actively contribute to constituting that people in a particular way.

Contrary to Pitkin (1967), who did not consider the mutually constitutive effects between symbols and their constituents, Lombardo and Meier's (2014) approach explicitly focuses on the human agency involved in symbol making and re-making and explores the power differentials at play within such processes. The conventional and routinized associations that grant a political symbol its seemingly natural character are by no means neutral. The sheer handful of women that feature on national coins and bills reflect traditionally gendered conceptions of politics and continue to shape the public sphere and the nation in overtly masculinist terms.
Following scholars such as Gamson (1997), Lombardo and Meier (2014) emphasize that symbols and, by extension, the processes through which symbols are attributed meaning set the boundaries of in- and outgroups. With respect to gender, they for instance argue that a symbolic construction of gender that attributes public roles to men and domestic ones to women shapes societal expectations toward men's and women's respective appearance, behaviour, and tasks. Symbolic representation does not only put forward specific presentations of gender (or of other groups, see Parkinson (2009) on the issue of ability); it also enshrines expectations on their roles, tasks, social position; thereby legitimising some and delegitimising others.

Lombardo and Meier's (2014) approach to symbolic representation is helpful to understand that the status of role model does not necessarily reflect the representative's intentions, nor does it require constituents' recognition or acceptance. To stand for others in an exemplary way requires, first and foremost, that one establishes a relationship of likeness with others. Representatives' descriptive traits, in this regard, facilitate their capacity to stand for their respective social groups. Representatives' capacity to stand as an example for their group depends, then again, on people's beliefs that representatives' life trajectories are laudable and that their success can be emulated by people like them. The establishment of such relations does not depend solely on the performances of descriptive representatives; although they are powerful agents in mediating these relations (see infra). Descriptive representatives stand before multiple audiences (Saward, 2010) and the label of role model is oftentimes conferred onto them by media, political commentators or parties; and this irrespective of their self-identifications, actions or the judgments of minority members for that matter.

As "bodies out of place" (Puwar, 2004), meaning (such as, being exemplary) is routinely attributed to descriptive representatives and they sometimes become role models against their own will. This insight was also central to Kanter's (1977) research on women's token status in American corporations in the 1970s. When the ratio of men to women is skewed in men's favour (as it continues to be in parliament), inter-group differences are often exaggerated, and women are reduced to tokens or mere symbolic representatives of their social category. Because men control the institution and its culture, women (and by extension, other minoritized groups) often exercise little control over the type of features that are considered characteristic of, let alone, exemplary of their social group (cf. Childs and Krook, 2008). Clearly, this attenuates descriptive representatives' responsibility for the effects which their ascribed exemplary character may have on others like them. Descriptive representatives, however, are not passive agents. How they engage with role model ascriptions and how they perform their group identity (through their representative claims, attire, communication style, etc.) may strengthen 
or counter-balance the prescriptive force of the label. Precisely because they are conceived as "standing in" for their social groups (as being somehow interchangeable with them), descriptive representatives hold normative power over them. Representatives' performances, therefore, directly reflect on their social groups: these performances help define their group in a particular way and, in doing so, can facilitate, respectively, limit the range of political demands which these groups may credibly make.

Role models' social differences feature, in this regard, as symbolic resources that bolster their representative authority. Such authority may do good: it may, for instance, help put issues on the political agenda. However, representatives' capacity to claim authority on matters of difference may also contribute to reducing the range of experiences, needs and interests of disadvantaged social groups. When too much weight is given to the experiences or perspective of political role models, these may end up supplanting the plurality of lived experiences and the diversity of intersecting social positions that characterise their social group (e.g., gender, race/ethnicity, age, sexuality, etc.). The exemplary function of a role model may serve as a standard and may project expectations on other, in particular less privileged, group members. Such normalisation may play in the hands of those actors who seek to hold members of disadvantaged groups responsible for their failure to move forward in life. More damaging still is the risk that role models' authority becomes so established, that it allows them to set the terms of the debate; making it increasingly difficult to voice alternative minority perspectives. These risks become all the more real when we consider that the label of role model is oftentimes extended by more privileged (sub)groups in society and seldom reflects the judgment of the most marginalised.

\section{The Power of Bodies: The Flemish-Nationalist Party}

To illustrate the ways in which role models may undermine the inclusiveness of representation processes we turn to the N-VA. The N-VA is a regionalist and separatist party that is part of the Flemish movement and strives for a peaceful and gradual secession of Flanders (Northern region of mainly Dutch-speaking inhabitants) from Belgium. Founded in 2001, the N-VA finds its origin in the People's Union ("Volksunie"), created in 1954. In recent years, N-VA has become the largest party of Flanders and presides the 2014-2019 Flemish government. It is also a coalition partner in the federal government. The party identifies as economically liberal and situates itself at the centre-right of the ideological spectrum (Deschouwer, 2012). N-VA adheres to a civic nationalism and various party officials, including some top politicians, have a migration background. Some party officials also grew up in blue collar households. This diversity helps legitimise the party's political agenda: politicians' references to their family background reinforce the people's party image of the N-VA and offers support to its meritocracy-based model of fairness. Like other right-liberal and conservative parties, the N-VA emphasises the responsibility of individuals to take command of their personal lives and invokes meritocratic ideals to legitimise cut-backs in public spending.

In our discussion of the N-VA, we will focus on two female politicians who have become role models over the last years. The first case refers to Liesbeth Homans. Following the 2014 regional elections, Homans was appointed Minister of Internal Affairs, Integration, Housing, Equal Opportunities and Poverty Reduction to the Flemish government. Before being nominated as minister to the Flemish government, Homans was the president of the public social services (known as OCMW) in Antwerp, one of the largest cities in Flanders. As a member of the municipal council, Homans was also charged with Social Affairs, Housing, Diversity and Integration, Society and Civil Services. The political portfolio of Homans is not arbitrary: her personal experiences with childhood poverty are well-known, and she has spoken on her personal experiences in the media. Zuhal Demir features as our second case. Demir's parents are Alevi Kurds who migrated in 1972 from Turkey to Flanders where her father worked in the coal mines. Demir was first elected into the Belgian federal parliament in 2010 and was re-elected in 2014. In February 2017, she was appointed State Secretary of Poverty Reduction, Equal Opportunities, People with a Disability, Urban Policy and Science Policy to the federal government.

What makes these politicians stand out as role models? Over the last years, neither Demir nor Homans explicitly self-identified as role models. Media and their political party, however, frequently present them as such. Meanwhile, Homans and Demir themselves, often refer to their personal experiences, and sometimes invoke them to legitimate policy proposals. This duality is useful to our theoretical argument: while it is often the majoritarian or dominant social group that attributes descriptive representatives the position of role model, descriptive representatives themselves can respond to these attributions in diverse ways so as to reinforce or undermine the normalising effect of their role model status.

Let us first consider the case of Liesbeth Homans. In a column, Lex Moolenaar (2012), political commentator for the local newspaper Gazet van Antwerpen, attributed Homans' extensive policy portfolio to her political ambition. He, in turn, ascribed this ambition to her personal experiences; growing up in a family with limited financial means. Moolenaar stated:

To finance her studies, she worked full-time at a supermarket. She had to pass her exams in June because she simply could not afford to lose the income of the summer months [when students can take reexaminations]. In terms of personal efforts to get ahead in life, Liesbeth Homans can be considered a role model. I believe that her personal background 
will, over the years to come, influence the social policy of Antwerp. (2012, own translation)

Homans herself contributed to the belief that she serves as a role model for people living in poverty. In an interview that preceded her appointment as Minister, Homans commented upon her recent divorce. She stated:

This [getting divorced] is not what you have in mind when you get married and decide to have children. But life is too short to keep feeling miserable. It [getting divorced] was not the most difficult decision I have had to make in life. After high school, it would have been easier for me to start working full time instead of going to university. But the rebel in me wanted to show what she was worth. From the age of 16 till 24 I worked in den Delhaize [a brand of supermarkets]: baker, butcher, cash register. First on the Boomsesteenweg [street name] and then in the Museumstraat [street name] in the South of the city [wealthier neighbourhood]. People liked me. They still like me; [I experience that] whenever I go shopping there. (Bultinck \& Faes, 2013, own translation)

This quote both evidences Homans' transition from poverty (now able to visit the shop she once had to work in) and her continued vulnerability (as a divorced mum). While her past and present vulnerabilities allow her to connect to destitute people (descriptive representation), her life narrative, personal strength and transition from poverty depict her as a role model (symbolic representation). While reflecting on her personal struggles, she defines poor people as resilient and rebellious, driven by a need to demonstrate their worthiness to society. This depiction is beyond reproach: by presenting the decision to file for divorce (no doubt, a highly emotional and difficult one) as less challenging than working her way through university, Homans does justice to the dire situation of people living in poverty and the self-sacrifices it often takes to get ahead in life.

The statement, however, reads differently in conjunction to the appeals to individual responsibility Homans regularly makes as Minister of Equal Opportunities and Poverty Reduction. In conjunction to these appeals, her life story becomes a standard by which other group members are measured and judged. Because alternative life narratives (e.g., of those unsuitable for higher education) are silenced by Homans' leading example, the prevailing conception that poverty reflects an inadequacy in one's work ethos or personality is reinforced. This successfully undermines empathetic stances toward the poor and recognition of the difficulties of overcoming poverty (such as, the lack of means that often inhibits people from taking necessary steps).

While Homans' emphasis on individual responsibility already shows from the former quote, another example from the same interview further evidences Homans' belief that destitute people should take control of their own lives. During the interview, Homans referred to an eye condition she had as a child. She invoked this illness as a means to showcase her moral outstanding when confronted with financial dilemmas. "By the age of 16, I had saved some money", Homans stated, "at that time, I could choose between a scooter-a Wallaroo [a brand of scooters]-or an eye operation. I gave priority to my eyes" (Bultinck \& Faes, 2013, own translation). Like the quote on working her way through college, this quote emphasises the sacrifices Homans made in life. Because Homans is an appointed official of the people, her emphasis on moral responsibility and individual responsibility transcends the mere anecdotal. It has normative implications in that it re-affirms extant beliefs that among the group of destitute people there are poor people undeserving of public efforts for redressing their lives.

The case of Zuhal Demir follows a similar pattern. However, this time, in reference to citizens originating from migration. Justifying Demir's 2017 appointment as State Secretary of Poverty Reduction, Equal Opportunities, People with a Disability, Urban Policy and Science Policy, Bart de Wever, president of the N-VA, stated:

We asked ourselves which of us would be best suited to tell the story of equal opportunities. Our story that people are provided opportunities, but that they also have [the obligation] to grasp these opportunities. [Our story that] if there is an economic revival, everyone benefits from it....Discrimination is real, but people should not shroud themselves in a culture of victimhood. A vast majority within the party believes that Zuhal Demir has the ability to confer this story in a credible manner during the remaining 2,5 years [of the legislature]. (Het Laatste Nieuws, 2017, own translation)

Statements, such as this one, pit Demir as a role model: her individual successes are believed to inspire others like her and to motivate them to grasp the opportunities available to them. In addition, and similar to Homans, the function of role model is not only ascribed to Demir. When intervening in public debates, Demir frequently invokes her identity and proclaims a sense of identification with her group. When Demir took the oath as State Secretary, she for instance wore her father's mineworker's scarf around her wrist. "It is the family's keep sake", Demir commented, "never forget where you come from, my father always told me" (Paelinck, 2017).

When intervening in political debates, Demir also routinely emphasises the need for positive stories and role models. 'YYes, you can' is my motto. I have also experienced mild forms of discrimination", Demir stated during the early days of her political career, "But I persisted, and many people with a migration background persisted and have become successful" (De Standaard, 2013, own translation). Although this statement weakens her exemplary function-highlighting that she is just one among the many people with a migration background that are 
successful-, accompanying statements in which Demir emphasises individuals' responsibility to grasp the opportunities that society offers them does elevate her individual successes to a model to be emulated.

Consider the following statement in which Demir reflects on her childhood and what it was like growing up in a migrant neighbourhood (Sioen, 2015, own translation):

At a certain point in time, my father took on his responsibilities and moved the family into a white neighbourhood. He personally introduced himself to the neighbours so as to break the ice. Because they were not that keen on having a Turkish family with five children move into the neighbourhood.

In this statement Demir acknowledges that ethnic minorities experience stereotyping and discrimination. But she attributes at least part of the responsibility for overcoming such discrimination to minority groups. They have a responsibility, like her father, to seek for ways to overcome structural inequality (de Jong \& Severs, 2017, p. 499). It is telling, in this regard, that Demir describes her role as State Secretary as that of a "realtor in opportunities". The metaphor of realtor suggests that Demir does not seek to transform societal structures (and, hence, tackle underlying inequalities). Instead, like a realtor, she positions herself in a "market of opportunities" and helps people navigate this market. The belief that the opportunities are available but that it is just a matter of grasping them obscures the structural character of (labour market, housing, etc.) inequalities and justifies policies that call on individuals' responsibility. In the opening paragraph of her policy declaration on poverty reduction and equal opportunities, Demir clearly stated that "as citizens, we all have the societal responsibility to grasp the available opportunities and take charge of our lives" (Abbeloos, 2017, own translation).

\section{One Swallow Does Not Make a Summer}

What we seek to demonstrate with our two cases is that role models are not in themselves good or bad. Instead, the impact they have on disadvantaged social groups depends upon the ways in which they perform their group identities. Although any performance of group identity is likely to have some prescribing effects ("the group is about", "group members should act like"), these effects are only damaging when representatives' performances conflict with other group members' experiences and leave no space for alternative stances to be heard. Under such circumstances, role models are likely to disempower group members, to undermine their selfesteem, participation, and the representation of their needs and interests.

Psychological studies have, for instance, demonstrated that role models only enhance group members' psychological well-being and self-confidence when the latter consider themselves as capable of attaining com- parable successes. Role models only inspire and promote feelings of self-enhancement when their life trajectory and professional successes seem attainable to others. When representatives' lived experiences or life trajectories are too far removed from people's proper lives and the opportunities available to them, role models provoke self-deflation (Lockwood \& Kunda, 1997). In close connection to this, studies (e.g., Taylor, Lord, \& Mclntyre, 2011) have revealed that role models only enhance people's self-confidence and performances when the latter believe that role models deserve their success. Stated differently, people only feel inspired and experience a boost in self-confidence when they ascribe role models' successes to the latter's intrinsic qualities (as opposed to tokenism) and believe that similar opportunities are available to them.

Although it is impossible to provide consistent findings on the ways in which disadvantaged groups relate to Zuhal Demir and Liesbeth Homans, there is some evidence that their acceptance is not fool-proof. Following Demir's appointment as State Secretary, the news site De Redactie. be interviewed people who share her migration background and who, like Demir, grew up in a mining family. Not all respondents felt inspired by her statements. One respondent, in particular, contested Demir's unnuanced emphasis on the opportunities available:

I don't agree with that [statement]. Our parents were illiterate and didn't have a clue on how to proceed. Zuhal was fortunate that her dad was a teacher before moving to Belgium. She was able to go to university. But that wasn't the case for everyone. A lot of migrant children, like me, had to take care of the household, help their parents with paper work, and go out and earn a living. (Sellam, 2017, own translation)

This comment illustrates that role models' capacity to elevate their proper experiences to a standard may divert attention from the continued vulnerabilities of historically disadvantaged groups. One swallow does not make a summer. Representatives' individual successes may disempower vulnerable others when these successes are depicted as readily attainable to all group members. Such generalisations-although communicating a message of hope-can backfire and be used to hold vulnerable group members responsible for their failure to move forward in life, or, at least, give them that feeling.

Clearly, the impact of role models is not limited to the levels of self-confidence and empowerment of members of disadvantaged groups. Their impact also extends to the structure of political debates, and their openness to dissenting voices. As Schattschneider (1960) but also, more recently, lyengar (1990) have shown, the way in which powerful and influential actors, such as role models, frame their political arguments has the capacity to set the terms of the debate. Role models' ability to draw on anecdotal evidence from their own lives enables them to keep certain conflicts off the table. As liv- 
ing proof, Homans and Demir evidence the opportunities that are available to members of their social groups. It is difficult to argue against representatives whom, despite their personal struggles - and perhaps, even in light of them-, emphasise people's responsibility to take charge of their lives.

In a double interview with Rachida Aziz, Belgian fashion designer and activist, Demir countered the critique that, because of her privileges (having a literate father and caring family) she would have no right to speak on issues of inequality and racial discrimination. She replied: "Hey, I also grew up in a ghetto, Rachida. The district [cité] of Waterschei. I also had to fight for everything myself. In life, nothing was ever handed to me. By no one" (Sioen, 2015, own translation).

Demir's statement that she never received any favours obscures the defining role her father has played in her life. Despite her many public expressions of gratitude toward him, Demir fails to recognise that other minority group members may not have had the same chances or opportunities in life (such as, having a present father). It is, however, difficult to rebut Demir's selective reading of her life because it so strongly resonates with the normative ideal of the responsible citizen. Demir's blindness to her proper privileges portrays her as a responsible citizen who, in the face of challenges, took charge of her life. She thereby zooms out the intersections of social positions of other group members, who might, for instance, not combine poverty with a literate family background.

The powerful ways in which role models may hold particular conflicts off the table and delegitimise alternative group perspectives may cause the already low political participation of members of disadvantaged groups to further decrease (cf. Giger, Rosset, \& Bernauer, 2012; Imig, 1996). As Schattschneider (1960) reminds us, these groups' lower political participation cannot simply be attributed to political disinterest. Such an explanation would miss the point that groups' failure to participate in politics "often reflects the suppression of the options and alternatives that reflect the needs of the nonparticipants" (Schattschneider, 1960, p. 105).

\section{Conclusion}

In this contribution, we have cautioned against accounts that unequivocally treat political role models, such as female politicians and politicians with migration backgrounds, as boosting the transformation and dismantling of hierarchical relations in society. Clearly, we do not contest the value of political role models or the emancipatory effects that stem from showcasing the ability to rule of historically disadvantaged groups. We, however, argue that role models' capacity to embody what the group is about produces normalising effects that may downplay the diversity of experiences of the members of their (ascribed or self-identified) social group and may, as such, reinforce (intersectional) inequalities. As shows from our examples, the label of role model is oftentimes extended by majoritarian or dominant groups in society. The label, in this sense, oftentimes reflects dominant groups' conceptions of what disadvantaged groups should be like or how they should behave.

Clearly, this is reason to also consider the potentially negative impacts role models can have on minority constituents' feelings of self-worth, their empowerment, and levels of political engagement. In this contribution, we have argued that these negative impacts can only be understood through the lens of symbolic representation. To date, scholarly accounts have mainly equated symbolic representation to citizens' attitudes and behaviour in reaction to descriptive representation. This failure to treat symbolic representation as a dimension in its own right has diverted attention from the dynamic processes of symbol making and re-making through which descriptive representatives become symbolic agents that ascribe appropriate behaviour to group members.

The fact that the label of role model is oftentimes extended to descriptive representatives attenuates the latter's responsibility for the effects which their ascribed exemplary character may have on others like them. Descriptive representatives, however, are not passive agents. How they engage with role model ascriptions and how they perform their group identity may strengthen or counter-balance the prescriptive force of the label, even though their capacity to do so is very much dependent on a number of contextual factors (such as, their position within their parties, etc.). Nonetheless, the fact that descriptive representatives can deploy their heightened visibility to counter-balance restrictive assumptions on their social group, makes some descriptive representatives preferable over others.

To convey our argument, we have mainly drawn upon what we consider negative examples. Although it is beyond the scope of this contribution to develop the point here in full, our analysis does offer insights into what could constitute a good role model. To undo, prevent or restrain the effects of normalisation, role models should perform their group identities in such a manner that the exceptionality of their successes cannot be invoked to penalise less successful group members, by narrowing the scope of intersections within that group. A good case in point forms US president Barack Obama who spoke up against tendencies to treat his individual success as evidence of a post-racial America. He, for instance, illustrated the limitations of a discourse of individual responsibility by stating that as a Senator he had, like many other male African-American professionals his age, been confused for a waiter at a reception. This statement powerfully conveys the insight that professional success (or individual effort) does not render people insensitive to (racial) stereotyping and discrimination (cf. Severs \& de Jong, 2018).

Good role models should, thus, strike a careful balance between evidencing that minorities too can be successful and acknowledging the structural character of in- 
equalities that continues to make it more difficult for members of disadvantaged groups to achieve comparable successes. Otherwise, role models end up doing the opposite of what they are supposed to do, disempowering instead of empowering those they serve as a role model. In today's political times, when politicians' personalities become increasingly important to winning over voters and cleavages between the empowered and the disempowered are growing, we need to exert caution in dealing with role models.

\section{Acknowledgements}

The research for this article was made possible by the financial support of the research council of the Vrije Universiteit Brussel (VUB) and the VUB Strategic Research Programme "Evaluating Democratic Governance in Europe"-EDGE, 2013-2018 (Eline Severs).

\section{Conflict of Interests}

The authors declare no conflict of interests.

\section{References}

Abbeloos, J. F. (2017, April 15). Staatssecretaris Zuhal Demir (N-VA) zet hoog in op de zelfredzaamheid van mensen in armoede en kansengroepen [State Secretary Zuhal Demir (N-VA) prioritizes the autonomy of destitute people and vulnerable groups]. De Standaard. Retrieved from http://www.standaard.be

Alcoff, L. (1991). The problem of speaking for others. Cultural Critique, 20, 5-32.

Atkeson, L. R. (2003). Not all cues are created equal: The conditional impact of female candidates on political engagement. The Journal of Politics, 65(4), 1040-1061.

Bobo, L., \& Gilliam, F. D. (1990). Race, sociopolitical participation, and black empowerment. The American Political Science Review, 84(2), 377-393.

Bultinck, B., \& Faes, J. (2013, August 17). Liesbeth Homans: Voor het eerst ben ik echt gelukkig [Liesbeth Homans: For the first time, I am truly happy]. De Standaard. Retrieved from http://www.standaard.be

Campbell, D. E., \& Wolbrecht, C. (2006). See Jane run: Women politicians as role models for adolescents. The Journal of Politics, 68(2), 233-247.

Childs, S., \& Krook, M. L. (2008). Critical mass theory and women's substantive representation. Political Studies, 56(3), 725-736.

Celis, K., Childs, S., Kantola, J., \& Krook, M. L. (2008). Rethinking women's substantive representation. Representation, 44(2), 99-110.

De Standaard. (2013, October 28). Dit helpt ons geen millimeter vooruit [This does not help one iota]. De Standaard. Retrieved from http://www.standaard.be

De Jong, S., \& Severs, E. (2017). Vertegenwoordiging in het grenzenland: De vermeende loyaliteiten van politici uit etnisch-culturele minderheidsgroepen. Res Publica, 59(4), 487-505.

Deschouwer, K. (2012). The politics of Belgium. Governing a divided society (2nd ed.). Basingstoke: Palgrave.

Diehl, P. (2015). Zum zusammenhang von legitimität, legitimation und symbolischer representation [On the connection between legitimacy, legitimation and symbolic representation]. In R. Voigt (Ed.), Legalität ohne legitimität? Carl Schmitts kategorie der legitimität [Legality or legitimacy? Carl Schmitt's categories of legitimacy]. (pp. 281-296). Berlin: Springer Verlag.

Diehl, P., \& Escudier, A. (Eds.). (2014). La représentation du politique: Histoire, concepts, symbols [The representation of politics: history, concepts and symbols]. Paris: Centre de recherches politiques de Sciences Po.

Disch, L. (2012). The impurity of representation and the vitality of democracy. Cultural Studies, 26(2/3), 207-222.

Dodson, D. L. (2006). The impact of women in Congress. Oxford: Oxford University Press.

Dolan, K. (2006). Symbolic mobilization? The impact of candidate sex in American elections. American Politics Research, 34(6), 687-704.

Dolan, K. (2011). Do women and men know different things? Measuring gender differences in political knowledge. The Journal of Politics, 73(1), 97-107.

Dovi, S. (2002). Preferable descriptive representation: Will just any woman, black or latino do? American Political Science Review, 96(4), 729-745.

Fenno, R. (2003). Going home. Black representatives and their constituents. Chicago: University of Chicago Press.

Franceschet, S., Krook, M. L., \& Piscopo, J. (Eds.). (2012). The impact of gender quotas. New York, NY: Oxford University Press.

Gamson, J. (1997). Messages of exclusion: Gender, movements and symbolic boundaries. Gender and Society, 11(2), 178-199.

Gay, C. (2002). Spirals of trust? The effect of descriptive representation on the relationship between citizens and their government. American Journal of Political Science, 46(4), 717-733.

Giger, N., Rosset, J., \& Bernauer, J. (2012). The poor political representation of the poor in comparative perspective. Representation, 48(1), 47-61.

Hansen, S. B. (1997). Talking about politics: Gender and contextual effects on political proselytizing. The Journal of Politics, 59(1), 73-103.

Het Laatste Nieuws. (2017, February 23). Zuhal Demir volgt Elke Sleurs op als staatssecretaris [Zuhal Demir replaces Elke Sleurs as State Secretary]. Het Laatste Nieuws. Retrieved from http://www.hln.be

Imig, D. R. (1996). Poverty and power. The political representation of poor Americans. Nebraska, NE: University of Nebraska Press.

Iyengar, S. (1990). Framing responsibility for political issues: The case of poverty. Political Behavior, 12(1), 
19-40.

Jones, P. E. (2014). Does the descriptive representation of gender influence accountability for substantive representation? Politics \& Gender, 10(1), 175-199.

Kanter, R. M. (1977). Some effects of proportions on group life. American Journal of Sociology, 82(5), 965-990.

Lawless, J. L. (2004). Politics of presence? Congresswomen and symbolic representation. Political Research Quarterly, 57(1), 81-99.

Lockwood, P., \& Kunda, Z. (1997). Superstars and me: Predicting the impact of role-models on the self. Journal of Personality and Social Psychology, 73(1), 91-103.

Lombardo, E., \& Meier, P. (2014). The symbolic representation of gender. A discursive approach. Aldershot: Ashgate.

Lowndes, J. (2013). Barack Obama's body: The presidency, the body politic, and the contest over American national identity. Polity, 45(4), 469-498.

Mansbridge, J. (1999). Should blacks represent blacks and women represent women? A contingent 'yes'. The Journal of Politics, 61(3), 628-657.

Moolenaar, L. (2012, December 29). Achtergrond van Homans zal sociaal beleid kleuren [Background of Homans will shape social policy]. Gazet van Antwerpen. Retrieved from http://www.gva.be

Paelinck, G. (2017, February 24) Het verhaal achter het rode sjaaltje rond de pols van Zuhal Demir [The story of the little red scarf around the wrist of Zuhal Demir]. De Redactie. Retrieved from http://deredactie.be

Parkinson, J. (2009). Symbolic representation in public space: Capital cities, presence and memory. Representation, 45(1), 1-14.

Phillips, A. (1995). The politics of presence: The political representation of gender, ethnicity, and race. Oxford: Oxford University Press.

Pitkin, H. F. (1967). The concept of representation. Berkeley and Los Angeles, CA: University of California Press.

Puwar, N. (2004). Space invaders: Race, gender and bodies out of place. Oxford and New York: Bloomsbury Publishing.

Reingold, B., \& Harrell, J. (2010). The impact of descriptive representation on women's political engage- ment: Does party matter? Political Research Quarterly, 63(2), 280-294.

Saward, M. (2010). The representative claim. Oxford: Oxford University Press.

Schattschneider, E. E. (1960). The semisovereign people: A realist's view of democracy in America. New York, NY: Holt, Reinhard and Winston.

Sellam, K. (2017, March 11). Wat vinden gastarbeiders van mijnwerkersdochter Zuhal Demir [What do immigrants think of daughter of a miner Zuhal Demir]? De redactie. Retrieved from http://deredactie.be

Severs, E., \& De Jong, S. (2018). Preferable minority representatives: Brokerage and betrayal. PS: Political Science and Politics, 51(8), 345-350.

Sioen, L. (2015, March 28). Racisme in Vlaanderen: Zuhal Demir vs. Rachida Azis. Hela,ik kom ook uit een getto, hoor [Racism in Flanders: Zuhal Demir vs. Rachida Azis. Hey, I also grew up in a ghetto, you know]. De Standaard. Retrieved from http://www.standaard.be

Strolovitch, D. (2006). Do interest groups represent the disadvantaged? Advocacy at the intersections of race, class and gender. The Journal of Politics, 68(4), 894-910.

Tate, K. (1991). Black political participation in the 1984 and 1988 presidential elections. American Political Science Review, 85(4), 1159-1176.

Taylor, C. A., Lord, C. G., \& Mclntyre, R. B. (2011). The Hillary Clinton effect. When the same role model inspires or fails to inspire improved performance under stereotype threat. Group Processes \& Intergroup Relations, 14(4), 447-459.

Verba, S., Burns, N., \& Schlozman, K. L. (1997). Knowing and caring about politics: Gender and political engagement. The Journal of Politics, 59(4), 1051-1072.

Williams, M. S. (1998). Voice, trust, and memory. Marginalized groups and the failings of liberal representation. Princeton, NJ: Princeton University Press.

Young, I. M. (1989). Polity and group difference: A critique of the ideal of universal citizenship. Ethics, 99(2), 250-274.

Young, I. M. (2006). Responsibility and global justice: A social connection model. Social Philosophy and Policy, 23(1), 102-130.

\section{About the Authors}

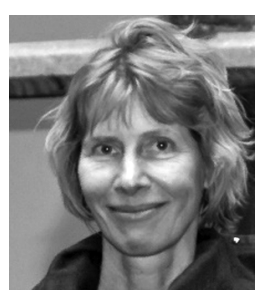

Petra Meier is Professor in Politics at University of Antwerp. Her research focuses on the representation of gender in politics and policies, investigating how political (sub)systems and their institutions (re)produce inequality. She recently edited Investigating Symbolic Representation (with Tania Verge, 2017, Politics, Groups, and Identities), Policymaking: Insights and Challenges from Gender and Other Equality Perspectives (with Emanuela Lombardo and Mieke Verloo, 2017, Journal on Women, Politics and Policies) and La Professionnalisation des Luttes pour L'Égalité (with David Paternotte, 2017, Academia L'Harmattan). 
Eline Severs is Assistant Professor in Political Science at Vrije Universiteit Brussel (VUB) and senior researcher at the VUB Strategic Program 'Evaluating Democratic Governance in Europe' (EDGE). Her research interests fall within the field of democratic theory. She is especially interested in democratic representation, the relationships between civil society and democratic governance, citizens' conceptions of democracy, and what it means to include historically disadvantaged groups. She recently edited a special issue on The Good Representative 2.0 (with Suzanne Dovi, University of Arizona) in PS: Political Science and Politics (2018). 